\title{
Evaluasi Penggunaan Antibiotik pada Pasien Infeksi Saluran Kemih di Instalasi Rawat Inap RSUP X di Klaten Tahun 2017
}

\section{Evaluation of Antibiotic Use in Urinary Tract Infection Patients in Center Hospital Klaten Indonesia}

\author{
Nawang Nawakasari*, Ambar Yunita Nugraheni \\ Fakultas Farmasi, Universitas Muhammadiyah Surakarta ${ }^{2}$ Name of Department, Name of Faculty, Name of \\ *E-mail: nawang.nawakasari@gmail.com
}

\begin{abstract}
Abstrak
Infeksi saluran kemih (ISK) merupakan infeksi yang yang ditandai dengan adanya bakteri yang tumbuh dan berkembang biak didalam saluran kemih melebihi jumlah normal. Berdasarkan Profil Kesehatan Indonesia, ISK merupakan 10 penyakit penyebab kematian terbanyak. Penggunaan antibotik yang tidak tepat dapat menyebabkan tidak tercapainya outcome terapi dan terjadi resistensi. Penelitian ini bertujuan untuk mengevaluasi ketepatan penggunaan antibiotik pada pasien Infeksi Saluran Kemih di RSUP di Klaten tahun 2017 meliputi tepat indikasi, tepat pasien, tepat obat, dan tepat dosis. Penelitian dengan metode non eksprimental pengambilan data secara retrospektif dan dianalisis secara deskriptif. Kriteria inklusi pada penelitian ini adalah pasien dewasa 18-64 tahun, pasien rawat inap menderita infeksi saluran kemih meliputi sistitis dan pyelonephritis, menerima antibiotik dan data rekam medik lengkap. Hasil penelitian menunjukkan bahwa pasien infeksi saluran kemih di RSUP di Klaten 2017 didapatkan sebanyak 72 pasien dengan 76 peresepan antibotik. Berdasarkan jumlah pasien dan jumlah peresepan antibiotik, hasil evaluasi menunjukkan tepat indikasi $100 \%$ dan tepat pasien $100 \%$, sedangkan hasil evaluasi tepat obat $96,05 \%$ dan tepat dosis sebanyak $27,63 \%$.
\end{abstract}

Kata Kunci: antibiotik, infeksi saluran kemih, evaluasi, ketepatan

\section{Abstract}

Urinary tract infections are infections are characterized by the presence of bacteria that grow and multiply in the urinary tract in excess of the normal amount. Based on the Indonesian Health Profile, urinary tract infections (UTI) are the 10 most common causes of death. Improper use of antibiotics can cause no therapeutic effect and resistance. This study aims to evaluate the accuracy of antibiotic use in patients with urinary tract infections in central hospital Klaten in 2017 covers the right indication, right patient, right medication, and right dosage. Research with nonexperimental methods of data retrieval retrospectively and analyzed descriptively. The inclusion criteria in this study were adult patients 18-64 years old, inpatients suffering from urinary tract infections including cystitis and pyelonephritis, receiving antibiotics and complete medical record data. The results showed that patients with urinary tract infections in RSUP in Klaten 2017 had 72 patients with 76 antibiotic prescriptions. Based on the number of patients, the evaluation results showed the right indication is $100 \%$ and the right patients is $100 \%$, while the exact evaluation results of the right drug is $96.05 \%$ and the right doses is $27,63 \%$. 
Keywords: antibiotics, urinary tract infections, evaluation, accuracy

\section{PENDAHULUAN}

Infeksi saluran kemih (ISK) merupakan infeksi yang terjadi pada pada ureter dan ginjal karena adanya mikroorganisme patogen yang berkembang biak, dan bertambah jumlahnya (Smeltzer dan Bare, 2008). Mikroorganisme patogen yang dapat menyebabkan infeksi saluran kemih yaitu Klebsiella pneumoniae, Escherichia coli, Staphyllococcus saprophyticus, Enterococcus faecalis, dan Proteus mirabilis (Flores et al., 2016), 2016). Pada 150 juta orang didunia diperkirakan kejadian ISK pada pria sebesar $3 \%$ dan wanita sebesar 12,65\% (Jhang dan Kuo, 2017). Pada wanita cenderung paling sering terkena infeksi saluran kemih, semasa hidup sekitar 50-60\% wanita terkena infeksi saluran kemih setidaknya satu kali, satu dari tiga wanita tersebut pada usia dewasa yaitu 24 tahun dan setidaknya mempunyai satu gejala ISK yang membutuhkan terapi antibiotik (Al-Badr dan Al-Shaikh, 2013). Pada anak-anak terdapat $2 \%$ anak laki-laki dan $7 \%$ anak perempuan yang menderita demam ditemukan kultur simptomatik dari gejala infeksi saluran kemih pada usia 6 tahun. Hal ini terjadi pada anakanak sekitar 3-7\% (Ramlakhan, 2014). Berdasarkan Riset Kesehatan Dasar (2013) penyakit sistem kemih masuk dalam 10 penyakit di Indonesia yang menyebabkan hospitalization, sehingga perlu penelitian lebih lanjut untuk mengurangi angka mortalitas yang disebabkan oleh ISK.

Terapi utama ISK adalah menggunakan antibiotik (Ghinorawa, 2015). Antibiotik yang digunakan berdasarkan Guideline on Urological Infections 2015 yaitu pada sistitis mengggunakan fosfomycin trometamo, Nitrofurantion macrocrystal, pivmecillinam, ciprofloxacin, levofloxacin, ofloxacin, cefadroxil, cefpodoxime proxetil, ceftibuten dan TMP-SMX (Trimethoprime dan Sulfamethoxazole). Terapi antibiotik pada pielonefritis meliputi ciprofloxacin, levofloxacin dan TMP-SMX. Penggunaan antibotik harus rasional dan tepat, karena jika penggunaan tidak tepat dapat menimbulkan resistensi, meningkatnya morbiditas, meningkatnya biaya pengobatan serta dapat menyebabkan kematian (Depkes RI, 2011). Pada penelitian Sutarman (2016) di RS Sukoharjo tahun 2014 didapatkan hasil 100\% tepat indikasi dan tepat pasien, $58,73 \%$ tepat obat serta $6,35 \%$ tepat dosis. Berdasarkan uraian diatas diperlukan penelitian untuk mengevaluasi tepat tidaknya penggunaan antibiotik pada pasien Infeksi Saluran Kemih di RSUP X Klaten tahun 2017 meliputi tepat indikasi, tepat pasien, tepat obat, dan tepat dosis.

\section{METODE PENELITIAN Jenis Penelitian}

Penelitian dengan metode noneksperimental dengan pengambilan data secara retrospektif dengan melihat catatan rekam medik. Data dievaluasi berdasarkan Panduan Praktis Klinis (PPK) RSUP X Klaten tahun 2017, DIH (Drug Interaction Handbook) 17th Edition, BNF (British National Formulary) 71 Edition 2016, Guideline on Urological Infections 2015 (Grabe, et al., 2015) dan Guideline Penatalaksanaan Infeksi Saluran Kemih dan Genitalia Pria 2015 (Ghinorawa, 2015).

\section{Definisi Operasional}

Infeksi saluran kemih yaitu infeksi yang ditandai dengan adanya bakteri yang tumbuh dan berkembang biak di dalam saluran kemih. Infeksi saluran kemih pada penelitian ini meliputi infeksi saluran kemih umum, cistitis dan pielonefritis berdasarkan diagnosis.

Tepat Indikasi adalah ketepatan pemberian obat sesuai dengan gejala dan diagnosis dokter berdasarkan PPK (Panduan Praktik Klinis) RSUP X Klaten 2017.

Tepat Pasien adalah ketepatan obat yang diberikan tidak kontraindikasi dan sesuai dengan keadaan pasien berdasarkan pedoman 
DIH (Drug Information Handbook) 17th Edition.

Tepat Obat adalah ketepatan pemilihan obat disesuaikan dengan tatalaksana terapi atau drug of choice, berdasarkan Pedoman Pelayanan Klinis (PPK) RSUP X Klaten 2017 dan Guideline on Urological Infections 2015 (Grabe, et al., 2015).

Tepat Dosis adalah ketepatan dosis sesuai dengan besaran, frekuensi, rute dan durasi pemberian obat berdasarkan DIH (Drug Information Handbook) 17th Edition, BNF (British National Formulary) 71 Edition 2016 dan Guideline Penatalaksanaan Infeksi Saluran Kemih dan Genitalia Pria 2015 (Ghinorawa, 2015).

Alat

Lembar pengumpulan data yang mengacu Panduan Praktis Klinis (PPK) RSUP $X$ Klaten, DIH (Drug Information Handbook) 17th Edition, BNF (British National Formulary) 71 Edition 2016, Guideline on Urological Infections 2015 (Grabe, et al., 2015) dan Guideline Penatalaksanaan Infeksi Saluran Kemih dan Genitalia Pria 2015 (Ghinorawa, 2015).

\section{Bahan}

Bahan pada penelitian ini berupa rekam medik pasien infeksi saluran kemih di instalasi rawat inap RSUP X Klaten 2017

\section{Populasi dan Sampel}

Populasi pada penelitian ini ialah semua pasien infeksi saluran kemih (ISK) di instalasi rawat inap RSUP X Klaten 2017

Sampel yang digunakan pada penelitian ini adalah sebagian populasi dengan inklusi yang memenuhi kriteria sebagai berikut:

a. Kriteria Inklusi: pasien dewasa 18-64 tahun, pasien rawat inap di RSUP X Klaten 2017 yang infeksi saluran kemih bawah (sistitis) dan infeksi saluran kemih atas (pielonefritis), pasien menerima antibiotik, data rekam medik lengkap meliputi identitas pasien (nama, usia, jenis kelamin), diagnosa dan karakteristik obat (nama obat, dosis, frekuensi, rute) dan data laboratorium (serum kreatinin, SGPT dan SGOT serta kultur urin jika terlampir). b. Kriteria Eksklusi: pasien ISK yang juga menderita infeksi lain

\section{Teknik Pengambilan Sampel}

Pengambilan sampel dilakukan pada penelitian ini adalah menggunakan metode purposive sampling.

\section{Analisis Data}

Data yang telah diperoleh dianalisis berdasarkan pedoman PPK RSUP X Klaten 2017, DIH (Drug Information Handbook) $17^{\text {th }}$ Edition, BNF (British National Formulary) 71 Edition 2016, Guideline on Urological Infections 2015 (Grabe, et al., 2015) dan Guideline Penatalaksanaan Infeksi Saluran Kemih dan Genitalia Pria 2015 (Ghinorawa, 2015). Data dievaluasi secara deskriptif dengan data disajikan dalam bentuk tabel dan pemberian penjelasan. Semua data yang didapat selama penelitian dikelompokkan dan dianalisis serta dihitung persentase tepat indikasi, tepat pasien, tepat obat dan tepat dosis.

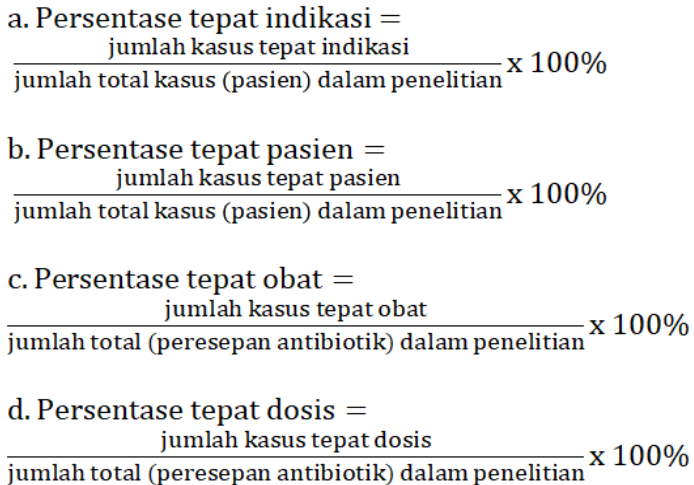

\section{HASIL DAN PEMBAHASAN}

Pasien yang menderita ISK di RSUP X Klaten pada tahun 2017 sebanyak 242 pasien. Pasien dengan kriteria inklusi usia (18-64 tahun) adalah sebanyak 121 pasien, sedangkan pasien yang memenuhi semua kriteria inklusi sejumlah 72 pasien, sehingga jumlah pasien yang tereksklusi sejumlah 170 pasien dikarenakan tidak memenuhi kriteria usia, pasien menderita infeksi lain dan terdapat pasien yang tidak menerima antibiotik.

Pada penelitian ini, karakteristik pasien meliputi jenis kelamin, umur, diagnosis dan penyakit penyerta. Data pasien infeksi saluran 
kemih berdasarkan jenis kelamin dan umur dapat dilihat pada tabel 1 .

Berdasarkan tabel 1, jenis kelamin wanita lebih banyak daripada jenis kelamin laki-laki dengan jumlah persentase 65,27 dan laki-laki sebanyak 34,72. Penelitian sesuai dengan hasil penelitian yang dilakukan Sutarman (2016), bahwa jumlah pasien ISK wanita lebih banyak dibandingkan laki-laki sejumlah 65,62\%. Pada penelitian Chair (2015), frekuensi kejadian penyakit ISK lebih banyak pada wanita dikarenakan saluran uretra pada wanita lebih pendek dan lurus serta dekat dengan anus sehingga bakteri lebih mudah masuk. Berdasarkan umur, hasil penelitian menunjukkan pada umur 45-55 dengan persentase 26,39\% (tabel 1). Umur yang lebih tua lebih rentan mengidap ISK, hal ini karena menipisnya saluran kandung kemih dan uretra, sehingga bakteri lebih mudah untuk masuk (Chair, 2015). Pada penelitian Purnomo (2011), menunjukkan bahwa 5- 6\% wanita mengalami ISK pada usia 18 sampai 40 tahun dengan penyebabnya adalah bakteri asimtomatik. Jumlah ini bertambah $20 \%$ pada usia lanjut sehingga penyakit ISK mengalami kenaikan pada usia dewasa yang lebih tua. Pada $10 \%$ wanita yang berusia $>65$ tahun, dilaporkan menderita ISK dalam 12 bulan terakhir. Kejadian ini meningkat pada wanita usia diatas 85 tahun sebanyak 30\% (Rowe and Manisha, 2014).

Pada penelitian ini, terdapat karakteristik pasien berdasarkan diagnosis seperti tabel 2 .

Pada tabel 2, menunjukkan diagnosa pasien yang menderita ISK di RSUP X Klaten 2017. Berdasarkan diagnosa ISK di RSUP X Klaten 2017, diagnosa infeksi saluran kemih

Tabel 1. Karakteristik pasien infeksi saluran kemih berdasarkan jenis kelamin dan umur di RSUP X Klaten 2017

\begin{tabular}{llcc}
\hline Karakteristik & & Jumlah & $\begin{array}{c}\text { Persentase (\%) } \\
(\mathrm{N}=72)\end{array}$ \\
\hline Diagnosa & ISK pielonefritis & 50 & 69,44 \\
& ISK sistitis & 22 & 30,56 \\
Jenis kelamin & Laki-laki & 25 & 34,72 \\
& Perempuan & 47 & 65,27 \\
Umur* (tahun) & 18-25 (remaja akhir) & 11 & 15,28 \\
& 26-35 (dewasa awal) & 11 & 15,28 \\
& 36-45 (dewasa akhir) & 16 & 22,22 \\
& 46-55 (lansia awal) & 19 & 26,39 \\
& 56-64 (lansia akhir) & 15 & 20,83 \\
\hline
\end{tabular}

*Keterangan: penggolongan umur berdasarkan Depkes RI (2009)

Tabel 2. Diagnosa infeksi saluran kemih di RSUP X Klaten 2017

\begin{tabular}{lllcc}
\hline No. & \multicolumn{1}{c}{ Diagnosa } & \multicolumn{1}{c}{ Gejala } & Jumlah & $\begin{array}{c}\text { Persentase (\%) } \\
(\mathrm{N}=72)\end{array}$ \\
\hline 1. & ISK atas & Nyeri pinggang & 48 & 66,67 \\
& (pielonefritis) & Demam & 26 & 36,11 \\
& & Mual & 20 & 27,78 \\
& & Hematuria & 3 & 2,78 \\
\hline 2. & ISK & Sering BAK & 3 & 4,17 \\
& bawah (sistitis) & Disuria & 4 & 5,56 \\
& Nyeri suprapubik & 22 & 30,56 \\
& & &
\end{tabular}


Tabel 3. Penyakit penyerta pasien infeksi saluran kemih di RSUP X Klaten 2017

\begin{tabular}{lcc}
\hline \multicolumn{1}{c}{ Diagnosa } & Jumlah & Persentase (\%) (N=72) \\
\hline Hipertensi & 6 & 8,33 \\
Diabetes Melitus & 5 & 6,94 \\
Asma & 1 & 1,39 \\
CKD (Chronic Kidney Disease) & 1 & 1,39 \\
AF (AtrialFibrilation) & 1 & 1,39 \\
\hline
\end{tabular}

Tabel 4. Karakteristik obat antibiotik pada pasien ISK di RSUP X Klaten 2017

\begin{tabular}{clcc}
\hline No. & Nama antibiotik & Jumlah & Persentase $(\%)(\mathrm{N}=72)$ \\
\hline 1. & Ceftriaxone & 46 & 63,88 \\
2. & Ciprofloxacin & 12 & 16,67 \\
3. & Cefotaxime & 10 & 13,89 \\
4. & Levofloxacin & 4 & 5,56 \\
5. & Cefixime & 2 & 2,78 \\
6. & Amoxicilin & 1 & 1,39 \\
7. & Meropenem & 1 & 1,39 \\
\hline
\end{tabular}

meliputi ISK bawah atau sistitis, ISK atas atau pielonefritis dan ISK. Diagnosa ISK digolongkan kembali menjadi ISK bawah (sistitis) dan ISK atas (pielonefritis) dengan melihat dari gejalanya berdasarkan PPK RSUP X Klaten yaitu pasien masuk golongan ISK sistitis dengan gejala sering buang air kecil, disuria, dan nyeri suprapubik, dan golongan ISK pielonefritis dengan gejala nyeri pinggang, demam, mual, dan hematuria.

Dalam penelitian terdapat beberapa penyakit lain yang menyertai penyakit ISK seperti yang terlihat dalam tabel 3 .

Pada tabel 3, terlihat bahwa penyakit penyerta infeksi saluran kemih di RSUP X Klaten 2017 tertinggi adalah hipertensi dengan jumlah persentase sebanyak 8,33\%, jumlah terbanyak kedua adalah DM (Diabetes Melitus) dengan jumlah persentase 6,94\%. American Diabetes Association (2013) disebutkan bahwa $9,4 \%$ penderita diabetes dapat megalami infeksi saluran kemih. Urin yang terkandung pada penderita DM mengandung glukosa, dimana glukosa adalah media tempat tumbuhnya bakteri dengan baik. Menurut National Kidney Foundation (2010), ISK tidak biasanya dapat menyebabkan kerusakan ginjal, namun jika ISK disertai dengan adanya batu ginjal dan pielonefritis yang berulang dapat menurunkan fungsi ginjal dan terjadi kerusakan ginjal jika tidak ditangani dengan baik.

Pada tabel 4 dapat dilihat penggunaan antibiotik untuk pasien ISK di RSUP $X$ Klaten 2017.

Berdasarkan hasil penelitian antibiotik terbanyak yang digunakan adalah ceftriaxone sebesar $63,88 \%$ (Tabel 4). Ceftriaxone merupakan golongan dari antibiotik sefalosforin generasi ke 3 yang mempunyai spektrum luas. Penggunaan ceftriaxone biasanya digunakan sebagai terapi empirik saat pasien masuk ke rumah sakit yang terindikasi mengalami infeksi (Durham et al., 2017). Syarat antibiotik untuk ISK adalah harus dapat ditoleransi dengan baik, dapat menyerap dengan baik mencapai konsentrasi urin yang inggi dan memiliki spektum aktivitas sempit pada patogen yang diketahui atau dicurigai (Coyle dan Prince, 2017). ISK dapat disebabkan oleh bakteri Gram negatif (E. Coli, Enterobacteraciae, Proteus mirabilis, Klebsiella) dan Gram positif (Staphylococcus aureus, Enterococcus) (Rowe and Manisha, 2014). Menurut Hauser (2013) mekanisme aksi ceftriaxone yaitu menghambat sintesis dinding sel bakteri dengan yang menghambat laju transpeptidasi 
sintesis peptidoglikan di dinding sel bakteri, sehingga biosintesis dinding sel terhambat. Ceftriaxone dapat melawan bakteri Gram (-) negatif dan Gram (+) positif, namun Gram (-) negatif lebih utama. Antibiotik lain yang digunakan untuk terapi ISK yaitu ciprofloxacin dengan persentase 16,67\% (Tabel. 4). Ciprofloxacin juga termasuk dalam antibiotik spektrum luas, yang memiliki manfaat untuk mengobati infeksi berat dan aman digunakan pada dosis rendah dengan rentang waktu yang pendek (Raini, 2016). Ciprofloxacin ini merupakan golongan kuinolon yang paling kuat dalam melawan bakteri gram negatif aerob dan efektif melawan Pseudomonas aeruginosa. Hal ini diimbangi juga bahwa ciprofloxacin dapat melawan bakteri Gram positif namun tidak terlalu poten (Hauser, 2013). Mekanisme aksi ciprofloxacin, dengan melakukan penghambatan pada DNA gyrase dalam organisme, sehingga terjadi penghambatan DNA superkoil dan merusak double-stranded DNA (DIH 17 $\left.{ }^{\text {th }}, 2007\right)$.

Pemberian obat selain antibiotik diberikan pada pasien infeksi saluran kemih digunakan untuk membantu meningkatkan kesembuhan dan kualitas hidup dari pasien.

Berdasarkan tabel 5, semua pasien ISK mendapatkan cairan elektrolit yang digunakan untuk menjaga keseimbangan cairan elektrolit dalam tubuh (IONI, 2008). Antitukak lambung salah satunya ranitidin, berperan membantu antibiotik dalam melawan infeksi yang disebabkan bakteri $H$. Pylori (Darnindro and Syam, 2013). Pemberian obat analgesik dan antipiretik dengan persentase $24,83 \%$ digunakan sebagai obat untuk mengurangi rasa nyeri pada pasien (O'neil, 2016). Hal tersebut sesuai dengan gejala infeksi saluran kemih yaitu salah satunya nyeri pada bagian suprapubik. Obat anti emetik atau anti mual digunakan untuk mengatasi mual dan muntah yang juga merupakan salah satu dari gejala ISK (Rose, 2016). Pada tabel 5, obat diare meliputi dulcolac dan new diatab dan terapi asma adalah nebuventolin.

Analisis ketepatan antibiotik pada pasien infeksi saluran kemih yaitu tepat indikasi, tepat pasien, tepat obat dan tepat dosis meliputi tepat besaran, tepat frekuensi dan tepat rute. Tepat indikasi adalah ketepatan pemberian obat yang sesuai dengan gejala dan diagnosa dokter. Hasil ketepatan indikasi dalam penggunaan antibiotik pada pasien ISK di RSUP X Klaten 2017 adalah 100\%. Hal ini dikarenakan semua pasien ISK yang menerima antibiotik di diagnosa ISK. Antibiotik berfungsi untuk terapi infeksi yang umumnya disebabkan oleh bakteri (Depkes RI, 2011).

Tepat pasien adalah terapi pemberian obat yang tidak kontraindikasi dan yang sesuai dengan kondisi pasien. Pada tabel 6 merupakan daftar antibiotik dan kontraindikasinya berdasarkan DIH (Drug Information Handbook) $17^{\text {th }}, 2007$.

Tabel 5. Karakteristik obat selain antibiotik pada pasien ISK di RSUP X Klaten 2017

\begin{tabular}{lcc}
\hline Golongan & Jumlah & Persentase golongan $(\%)(\mathrm{N}=72)$ \\
\hline Elektrolit & 72 & 100 \\
Anti tukak lambung & 62 & 86,11 \\
Analgesik-antipiretik & 59 & 81,94 \\
Anti emetik & 28 & 38,89 \\
Obat DM & 8 & 11,11 \\
Vitamin & 7 & 9,72 \\
Anti hipertensi & 6 & 8,33 \\
Obat Diare & 4 & 5,56 \\
Kortikosteroid & 3 & 4,17 \\
Terapi asma & 1 & 1,39 \\
Diuretik & 1 & 1,39 \\
\hline
\end{tabular}


Berdasarkan hasil evaluasi ketepatan pasien adalah $100 \%$, karena semua pasien tidak memiliki hipersensitifitas terhadap antibiotik yang diberikan. Evaluasi ketepatan pasien juga mempertimbangkan kondisi pasien seperti fungsi ginjal yaitu dengan melihat nilai $\mathrm{ClCr}$ dan fungsi hati dengan melihat nilai SGPT dan SGOT.

Tepat obat merupakan terapi obat yang diberikan sesuai dengan drug of choice. Tepat obat dievaluasi berdasarkan kesesuaian pemberian obat dengan acuan PPK (Panduan Praktik Klinis) ISK RSUP X Klaten 2017 dan Guideline on Urological Infections 2015 (Grabe, 2015). Tepat obat dan tepat dosis dievaluasi dengan membandingkan jumlah peresepan antibiotik yang digunakan oleh pasien, karena adanya beberapa pasien yang mendapatkan penggantian jenis antibiotik.

Pasien ISK RSUP X Klaten 2017 mendapatkan terapi antibitik empiris lebih banyak dibandingkan terapi definitifnya dikarenakan belum dilakukan pemeriksaan lebih lanjut mengenai kultur urin. Berdasarkan Depkes RI (2011), penggunaan antibiotik empiris dilakukan jika bakteri penyebabnya belum diketahui secara pasti.
Penggunaan antibiotik empiris bertujuan menghambat tumbuhnya bakteri yang diduga penyebab infeksi, hal ini dilakukan sebelum didapatkan hasil pemeriksaan mikrobiologi, sedangkan terapi antibiotik definitif diberikan jika sudah diketahui jenis bakteri yang menyebabkan infeksi. Tujuannya untuk menghambat bakteri yang sudah diketahui secara pasti sebagai penyebab infeksi. Berdasarkan tabel 6 didapatkan hasil ketepatan obat $96,05 \%$, dengan hasil tidak tepat obat $3,95 \%$. Ketidaktepatan obat terjadi pada pemilihan antibiotik definitif, dimana pasien dengan hasil kultur bakteri E. Coli dan Staphylococcus aureus mendapatkan antibiotik yang tidak sesuai dengan hasil kulturnya. Berdasarkan Guideline on Urological Infections 2015 (Grabe, 2015)) drug of choice terapi untuk bakteri E. Coli adalah antibiotik golongan floroquinolon. Pada awal terapi, pasien mendapatkan antibiotik ciprofloxacin dimana sudah tepat obat (tabel 6), namun kemudian mendapatkan penggantian antibiotik ceftriaxone sehingga menjadi tidak tepat obat. Pada hasil kultur bakteri Staphylococcus aureus, pilihan terapi antibiotiknya adalah TMP-SMX atau

Tabel 6. Ketepatan obat antibiotik pada pasien infeksi saluran kemih di RSUP X Klaten 2017

\begin{tabular}{|c|c|c|c|c|}
\hline \multirow[t]{2}{*}{ Indikasi } & \multirow{2}{*}{$\begin{array}{l}\text { Nama } \\
\text { antibiotik }\end{array}$} & \multirow{2}{*}{$\begin{array}{l}\text { Antibiotik untuk ISK umum, sistitis } \\
\text { dan pielonefritis }\end{array}$} & \multicolumn{2}{|c|}{ Jumlah Ketepatan Obat } \\
\hline & & & Tepat obat & Tidak tepat obat \\
\hline \multirow{6}{*}{$\begin{array}{l}\text { ISK bawah } \\
\text { (sistitis) }\end{array}$} & Ceftriaxone & $\mathrm{TMP}+\mathrm{SMX}$ & 12 & - \\
\hline & & Floroquinolone & & \\
\hline & Ciprofloxacin & Nitrofurantion & 4 & - \\
\hline & Levofloxacin & Cephalosporin & 2 & - \\
\hline & Cefotaxime & Carbapenem, & 4 & - \\
\hline & Meropenem & Antibiotik sesuai & 1 & - \\
\hline \multirow[t]{6}{*}{$\begin{array}{l}\text { ISK atas } \\
\text { (pielonefritis) }\end{array}$} & Ceftriaxone & $\begin{array}{l}9 \text { kultur (PPK ISK } \\
\text { RSUP X Klaten 2017) }\end{array}$ & 32 & 2 \\
\hline & Ciprofloxacin & ${ }^{*} E$. Coli : floroquinolon & 8 & - \\
\hline & Cefotaxime & **Staphylococcus aureus: TMP- & 6 & - \\
\hline & Levofloxacin & SMX (Guideline on Urological & 2 & - \\
\hline & Cefixime & Infections 2015 (Grabe, 2015)) & 2 & - \\
\hline & Amoxicillin & & & 1 \\
\hline Total & & & 73 & 3 \\
\hline Persentase $(\%$ & $=76)$ & & 96,05 & 3,95 \\
\hline
\end{tabular}

Keterangan:*hasil kultur urin bakteri E. Coli

**hasil kultur urin Staphylococcus aureus 
Tabel 7. Ketepatan dosis obat antibiotik pada pasien infeksi saluran kemih di RSUP X Klaten 2017

\begin{tabular}{|c|c|c|c|c|}
\hline Antibiotik & $\begin{array}{l}\text { Ketepatan } \\
\text { dosis }\end{array}$ & Indikasi & Keterangan & $\begin{array}{l}\text { Jumlah }(\%) \\
\mathrm{N}=76\end{array}$ \\
\hline \multirow{5}{*}{ Cefotaxime } & Tepat dosis & ISK sistitis & Dosis tepat & $2(2,63 \%)$ \\
\hline & \multirow{4}{*}{$\begin{array}{l}\text { Tidak tepat } \\
\text { dosis }\end{array}$} & ISK sistitis & Tidak tepat frekuensi dan durasi & $1(1,31 \%)$ \\
\hline & & & Tidak tepat durasi & $1(1,31 \%)$ \\
\hline & & ISK pielonefritis & Tidak tepat frekuensi dan durasi & $1(1,31 \%)$ \\
\hline & & & Tidak tepat durasi & $5(6,57 \%)$ \\
\hline \multirow[t]{4}{*}{ Ceftriaxone } & \multirow[t]{2}{*}{ Tepat dosis } & ISK sistitis & Dosis tepat & $12(15,78 \%)$ \\
\hline & & ISK pielonefritis & Dosis tepat & $4(5,26 \%)$ \\
\hline & \multirow[t]{2}{*}{$\begin{array}{l}\text { Tidak tepat } \\
\text { dosis }\end{array}$} & ISK pielonefritis & $\begin{array}{l}\text { Dosis lebih dan tidak tepat } \\
\text { durasi }\end{array}$ & $1(1,31 \%)$ \\
\hline & & & Tidak tepat durasi & $29(38,15 \%)$ \\
\hline Cefixime & $\begin{array}{l}\text { Tidak tepat } \\
\text { dosis }\end{array}$ & ISK pielonefritis & Tidak tepat durasi & $2(2,63 \%)$ \\
\hline \multirow[t]{5}{*}{ Ciprofloxacin } & Tepat dosis & ISK sistitis & Dosis tepat & $3(3,94 \%)$ \\
\hline & \multirow[t]{4}{*}{$\begin{array}{l}\text { Tidak tepat } \\
\text { dosis }\end{array}$} & ISK sistitis & $\begin{array}{l}\text { Dosis lebih dan tidak tepat } \\
\text { durasi }\end{array}$ & $1(1,31 \%)$ \\
\hline & & ISK pielonefritis & $\begin{array}{l}\text { Dosis lebih dan tidak tepat } \\
\text { durasi }\end{array}$ & $1(1,31 \%)$ \\
\hline & & & $\begin{array}{l}\text { Dosis kurang dan tidak tepat } \\
\text { durasi }\end{array}$ & $6(7,89 \%)$ \\
\hline & & & Tidak tepat durasi & $1(1,31 \%)$ \\
\hline \multirow[t]{3}{*}{ Levofloxacin } & \multirow{3}{*}{$\begin{array}{l}\text { Tidak tepat } \\
\text { dosis }\end{array}$} & ISK sistitis & Dosis lebih & $2(2,63 \%)$ \\
\hline & & ISK pielonefritis & $\begin{array}{l}\text { Dosis lebih dan tidak tepat } \\
\text { durasi }\end{array}$ & $1(1,31 \%)$ \\
\hline & & & Tidak tepat durasi & $1(1,31 \%)$ \\
\hline Amoxicillin & $\begin{array}{l}\text { Tidak tepat } \\
\text { dosis }\end{array}$ & ISK pielonefritis & $\begin{array}{l}\text { Dosis lebih, tidak tepat frekuensi } \\
\text { dan tidak tepat durasi }\end{array}$ & $1(1,31 \%)$ \\
\hline Meropenem & $\begin{array}{l}\text { Tidak tepat } \\
\text { dosis }\end{array}$ & ISK sistitis & Tidak tepat frekuensi & $1(1,31 \%)$ \\
\hline
\end{tabular}

trimethroprim-sulfamethoxazole, sedangkan pasien menerima terapi antibiotik ceftriaxone sehingga menjadi tidak tepat obat. Pada pasien juga terjadi ketidaktepatan penggunaan antibiotik dengan terapi antibiotik amoxicillin. Berdasarkan PPK RSUP X Klaten 2017, amoxicillin bukan merupakan pilihan untuk ISK. Ketidaktepatan obat dapat mengakibatkan meningkatnya tingkat resistensi obat, berdampak pada kondisi klinis yang mengakibatkan tidak tercapainya efek terapi dan dapat menimbulkan efek samping lainnya (Depkes RI, 2011).

Tepat dosis yaitu kesesuaian besaran, frekuensi, rute dan durasi pemberian. Ketepatan dosis berdasarkan DIH (Drug Information Handbook) 17 $7^{\text {th }}$ 2007, BNF (British National Formulary) 71 Edition 2016 dan Guideline Penatalaksanaan Infeksi Saluran Kemih dan Genitalia Pria 2015. Berikut data ketepatan dosis pasien rawat inap saluran infeksi kemih di RSUP X Klaten 2017.

Pada tabel 7 menunjukkan bahwa jumlah obat yang tidak memenuhi ketepatan dosis adalah sebanyak $72,36 \%$ dan obat antibiotik yang memenuhi ketepatan dosis adalah $27,63 \%$. Pemberian dosis yang tidak tepat dapat mengakibatkan toksisitas dan resistensi obat (Depkes RI, 2011). Pada evaluasi ketepatan dosis juga memperhatikan fungsi ginjal dengan melihat nilai $\mathrm{ClCr}$ dan fungsi hati dengan melihat nilai SGPT dan SGOT. Pada pemeriksaan laboratorium terdapat 18 pasien yang tidak memiliki data serum kreatinin. Nilai normal serum kreatinin di RSUP X Klaten 2017 adalah pada range 0,6$0,9 \mathrm{mg} / \mathrm{dL}$. Perhitungan nilai klirens kreatinin 
ini berdasarkan rumus Jellife. Pada DIH (2007) penggunaan dosis antibiotik seperti ciprofloxacine, cefixime, cefotaxime, levofloxacine, meropenem perlu disesuaikan jika nilai $\mathrm{ClCr}$ pasien $\leq 50 \mathrm{~mL} /$ menit. Hasil evaluasi ketepatan dosis menunjukkan bahwa 76,32\% (52 kasus dari 76 peresepan antibiotik) tepat dosis. Pasien yang mendapatkan antibiotik golongan kuinolon (ciprofloxacin dan levofloxacin) mempunyai nilai $\mathrm{ClCr}>50 \mathrm{~mL} /$ menit sehingga tidak diperlukan penyesuaian dosis. Pada pasien yang menggunakan ceftriaxone dengan diagnosa $\mathrm{CKD} \quad(\mathrm{ClCr} \quad 12 \mathrm{ml} / \mathrm{menit})$, mendapatkan ceftriaxone 1 gram/12 jam. Penggunaan ceftriaxone pada pasien yang mengalami gangguan fungsi ginjal adalah maksimal 2 g/hari (DIH, 2007), sedangkan pada pasien yang mendapatkan cefotaxime dengan $\mathrm{ClCr} 21 \mathrm{~mL} /$ menit, berdasarkan DIH (2007), pasien yang mendapatkan cefotaxime dengan nilai $\mathrm{ClCr} 10-50 \mathrm{~mL} / \mathrm{menit}$ harus diberikan tiap $1 \mathrm{~g} / 8-12$ jam per harinya.

Fungsi hati juga dipertimbangkan dengan melihat nilai SGPT (Serum Glutamic Pyruvic Transminase) dan SGOT (Serum Glutamic Oxaloasetic Transminase). Range nilai normal untuk SGPT dan SGOT di RSUP X Klaten 2017 adalah 7,0-31,0 U/L. Berdasarkan evaluasi, terdapat 28 pasien yang tidak memiliki data SGPT dan SGOT. Jumlah pasien yang memiliki nilai SGPT dan SGOT yang melebihi rentang normal adalah 13 pasien. Berdasarkan Kemenkes RI (2011), nilai SGPT dan SGOT yang melebihi 1,25$2,5 \mathrm{x}$ dari batas normal termasuk dalam kategori ringan, $>2,5-5 \mathrm{x}$ dari batas normal termasuk kategori sedang, dan >5-10x dari batas normal termasuk kategori berat. Pada penelitian ini 12 pasien masuk kategori ringan dengan rentang peningkatan SGPT dan SGOT antara 38,75-77,5 U/L. Terdapat 1 pasien yang termasuk kategori sedang dengan nilai SGPT 147,1 U/L dan SGOT 143,2 U/L, serta tidak ada pasien yang termasuk dalam kategori berat. Berdasarkan BNF 71 (2016) penggunaan ceftiaxone dan cefotaxime perlu dilakukan penyesuaian dosis jika pasien dengan gangguan fungsi hati berat dengan mengurangi dosisnya.

Analisis durasi berdasarkan Guideline Penatalaksanaan Infeksi Saluran Kemih dan Genitalia Pria 2015 (Ghinorawa, 2015), bahwa lama pemberian antibitotik pada pasien yang menderita infeksi saluran kemih bawah atau sistitis adalah 1-7 hari sedangkan pada pasien infeksi saluran kemih atas atau pielonefritis adalah $10-14$ hari. Beberapa pasien tidak memenuhi durasi pemberian antibiotik karena adanya penggantian antibiotik.

Peneliti menggolongkan diagnosa ISK menjadi ISK atas (pielonefritis) dan ISK bawah (sistitis) dengan melihat gejala pasien yang tercantum dalam data rekam medik. Pada ketepatan dosis, durasi yang analisis tidak dapat dievaluasi secara akurat karena tidak diketahui jumlah obat yang dibawa pulang oleh pasien, sehingga data durasi penggunaan obat menjadi kurang.

\section{KESIMPULAN}

Evaluasi penggunaan obat merupakan salah satu kegiatan farmasi klinik yang bertujuan untuk memastikan obat yang diberikan untuk terapi pada pasien rasional, aman dan efektif (Depkes RI, 2016). Hasil penelitian dari 72 pasien ISK di RSUP $X$ Klaten dengan jumlah 76 peresepan antibiotik menunjukkan bahwa tepat indikasi $100 \%$ dan tepat pasien $100 \%$, sedangkan hasil evaluasi tepat obat $96,05 \%$ dan tepat dosis sebanyak 27,63\% dari 76 kasus peresepan antibiotik.

\section{Daftar Pustaka}

American Diabetes Association (ADA), 2013, Diabetes Care, Volume 36 1: S67 http://care.diabetesjournals.org/content/36/Supplement_1/S11.full.pdf. 
Al-Badr A., dan Al-Shaikh G., 2013, Recurrent Urinary Tract Infections Management in Women, Indian Medical Journal, 13 August, 359-367.

Badan Pengawas Obat dan Makanan Republik Indonesia (BPOM RI), 2008, Informasi Obat Nasional Indonesia (IONI). BPOM RI, Jakarta.

BNF, 2016, British National Formulary 71th Edition, 71st ed., BMJ Group, London United Kingdom

Chair M. G., Bartoletti R., Bjerklund J. T. E., Cai T., Çek M., Köves B., 2015, EAU guidelines for the management of urinary and male genital tract infections, Urinary Tract Infection (UTI) Working Group of the Health Care Office (HCO) of the European Association of Urology (EAU), European Urology, 40(5), 576-588.

Coyle, E. A and Prince R.A., 2017, Urinary Tract Infection and Prostatitis, in Dipiro, J. T., Robert, L. T., Gary, C. Y., Gary, R. M., Barbara, G. W., and Michael, P., (Eds) Pharmacotherapy: A Pathophysiologic Approach, Tenth Edition, The McGraw-Hill Companies Inc, 7 th., USA.

Darnindro N. and Syam A.F., 2013, Current Diagnosis and Management of Helicobacter pylori, Faculty of Medicine University of Indonesia Journal, 14 (3), 165-173.

Depkes RI, 2011, Pedoman Umum Penggunaan Antibotik, Departemen Kesehatan RI, Jakarta.

Depkes RI, 2016, Peraturan Menteri Kesehatan No. 72 Tentang Standar Pelayanan Kefarmasian di Rumah Sakit, Departemen Kesehatan RI, Jakarta.

DIH, 2007, Drug Information Handbook 17th edition, America Pharmacist Association, New York.

Durham S.H., Aq-id B., Wingler M.J. and Eiland L.S., 2017, Appropriate Use of Ceftriaxone in the Emergency Department of a Veteran' s Health Care System, Journal of Pharmacy Technology, 33(6), 215-218.

Flores M., Walker J. N., Caparon, M., dan Hultgren S. J., 2016, Urinary Tract Infections: Epidemiology, Mechanisms of Infection and Treatment Options, Department of Molecular Microbiology and Center for Women's Infectious Disease Research, Nat Rev Microbiol, University School of Medicine ,Washington.

Ghinorawa T., 2015, Penatalaksanaan Infeksi Saluran Kemih dan Genitalia Pria 2015 2nd ed., Ikatan Ahli Urologi Indonesia, Surabaya.

Grabe M., Bartoletti R., Johansen T.E.B., Cai T., Cek M., Koves B., et al., 2015, Guidelines on Urological Infections, European Association of Urology, March 2015

Hauser, R. A., (2013) Antibiotics basics for clinicians the ABCs of choosing the right antibacterial agent. Second Edi, Chicago: Depastement of Microbiologgy/Immunology and Medicine Northwestern University, Chicago, Illinois.

Jhang J. F., dan Kuo H. C., 2017, Recent Advance in Recurrent Urinary Tract Infection from Pathogenesis and biomarkers to Prevention, Tzu Chi Medical Journal, 29(2), 65-71.

Kementerian Kesehatan RI, 2011, Tatalaksana Klinis Infeksi HIV dan Terapi Antiretroviral Pada Orang Dewasa, II., Kementerian Kesehatan RI, Jakarta.

National Kidney Foundation, 2010, Urinary Tract Infections, National Kidney Foundation Organization, New York. Http://www.kidney.org 
O’neil C.K., 2016, Pain Management, Dalam DiPiro, J. T. et al., eds. Pharmacotherapy Principal and Practice, McGraw-Hill Education, New York, pp. 521-531.

PPK, Panduan Praktik Klinis RSUP X Klaten, 2017, Jawa Tengah

Purnomo, B., 2011, Dasar-Dasar Urologi, Ed 3, Sagung Seto, Jakarta

Raini M., 2016, Antibiotik Golongan Fluorokuinolon: Manfaat dan Kerugian, Pusat Penelitian dan Pengembangan Biomedis dan Teknologi Dasar, Kesehatan Badan Litbangkes, Jakarta. 26 No. 15, 1169-1174.

Ramlakhan S., Singh V., Stone J. and Ramtahal A., 2014, Clinical Medicine Insights : Pediatrics Clinical Options for the Treatment of Urinary Tract Infections in Children, Clinical Medicine Pediatric, 31-37.

RISKESDAS, 2013, Riset Kesehatan Dasar, Badan Penelitian dan Pengembangan Kesehatan Kementerian RI. (Diakses pada 14 Januari 2019).

Rose W.E., 2016, Urinary Tract Infection, Dalam DiPiro, J. T. et al., eds. Pharmacotherapy Principal and Practice, McGraw-Hill Education, New York, pp. 521-531.

Rowe T.A. and Manisha J., 2014, Urinary tract infection in older adults, National Institutes of Health, 9 (5), 1-15

Smeltzer S. C., dan Bare B. G., 2008, Textbook of Medical-Surgical Nursing, 8th edition, Philadelphia: Lippincott Williams \& Wilkins.

Sutarman R. H., 2016, Evaluasi Penggunaan Antibiotik pada Pasien Infeksi Saluran Kemih Rawat Inap di RS X Kabupaten Sukoharjo Tahun 2004, Skripsi, Fakultas Farmasi, Universitas Muhammadiyah Surakarta, Surakarta. 